\title{
EDUKASI DAN PELATIHAN \\ TATA LAKSANA DEMAM PADA ANAK KELURAHAN MANARAP LAMA KABUPATEN BANJAR, KALIMANTAN SELATAN
}

\author{
Malisa Ariani $^{1 *}$, Eirene E. M Gaghauna ${ }^{2}$ \& Darini Kurniawati ${ }^{3}$ \\ 1,2,3 Universitas Sari Mulia Banjarmasin \\ *email: sashaariani2323@gmail.com
}

\begin{abstract}
ABSTRAK
Setiap anak di seluruh dunia pasti pernah mengalami demam. Demam adalah salah satu tanda gejala dari penyakit pada anak. Demam merupakan bagian dari mekanisme pertahan tubuh dalam menghadapi berbagai mikroorganisme patogen. Di negara maju, sekitar 10-20\% anak dibawa ke UGD dan rawat jalan karena mengalami demam. Berdasarkan hasil wawancara singkat kepada beberapa orangtua di wilayah Kelurahan Manarap Lama, Kabupaten Banjar, Kalimantan Selatan didapatkan bahwa orang tua kurang mengetahui tentang cara pengukuran suhu tubuh, batas ambang suhu tubuh normal, cara mengatasi demam dan menghitung dosis obat demam untuk anak. Maka dari itu, adanya ketidakpahaman dan ketidaktahuan dari orangtua mengenai konsep demam dan tatalaksananya untuk anak sehingga diadakan kegiatan Pengabdian kepada Masyarakat terkait pemberian edukasi dan pelatihan terkait tatalaksana demam pada anak di Kelurahan Manarap Lama, Kabupaten Banjar, Kalimantan Selatan. Metode pelaksanaan dibagi menjadi beberapa tahapan meliputi tahap persiapan, tahap observasi dan wawancara, tahap implementasi kegiatan edukasi dan pelatihan tatalaksana demam pada anak, tahap kunjungan ulang untuk evaluasi. Hasil yang didapatkan dari kegiatan ini, pemahaman orangtua meningkat sebelum dan setelah dilaksanakan kegiatan edukasi dan pelatihan ini (mengetahui cara mengukur suhu tubuh, cara mengatasi demam dan menghitung dosis obat demam untuk anak). Orangtua juga merasa bersyukur dan senang kegiatan ini dilaksanakan. Edukasi dan pelatihan yang dilaksanakan ini dapat meningkatkan pengetahuan orangtua terkait konsep demam dan tatalaksana demam pada anak. Sehingga, meningkatnya pengetahuan orangtua terkait penanganan demam dapat menurunkan hal-hal yang membahayakan akibat demam seperti kejadian kejang demam dan lainnya.
\end{abstract}

Kata Kunci : Tatalaksana Demam, Anak

\section{A. PENDAHULUAN}

Demam merupakan salah satu tanda klinis yang paling umum terjadi pada anak sehingga membuat anak dibawa untuk konsultasi ke pelayanan kesehatan terkait kondisi yang dialaminya (Chiappini, Bortone, Galli, \& de Martino, 2017).
Demam merupakan kondisi suhu tubuh diatas batas normal yaitu lebih dari $37,5^{\circ} \mathrm{C}$. Suhu tubuh meningkat sebagai respon terhadap infeksi atau peradangan yang dapat disebabkan oleh bakteri, virus atau pathogen lain (Butarbutar, Sholikhah, \& Napitupulu, 2018). 
Di Negara maju, sekitar 10-20\% anak dibawa ke UGD dan rawat jalan karena mengalami demam (Korkut, Y, 2018). Badan Pusat Statistik di Indonesia tahun 2012 mencatat bahwa angka kejadian anak demam sebanyak 90.245 orang dan pada tahun 2013, anak mengalami demam sebanyak 112.511 orang anak (Doloksaribu, T, M \& Siburian, M, 2017). Provinsi Kalimantan Selatan merupakan daerah tropis sehingga banyak kasus penyakit infeksi yang tanda gejalanya berupa demam. Tercatat data dari Puskesmas Basirih Banjarmasin bahwa angka kejadian demam pada bulan Januari - Mei 2019 terjadi sebanyak 426 anak diantaranya kasus Febris (237 anak), Demam Typoid (69 anak), DBD (32 anak), Tonsilitis (88 anak). Angka kejadian demam tersebut termasuk tinggi seiring dengan masih banyaknya angka kejadian penyakit tropis (Rifaldi, I \& Wulandari, D. K, 2020).

Penanganan demam pada anak sangat tergantung pada peran orangtua, terutama ibu. Jika demam tidak segera ditangani secara tepat maka akan sangat membahayakan nyawa anak. Ibu yang mengetahui tentang demam dan memiliki sikap yang baik dalam melakukan perawatan maka dapat menentukan penanganan demam yang terbaik untuk anaknya (Butarbutar, Sholikhah, \& Napitupulu, 2018; Doloksaribu, T, M \& Siburian, M, 2017). Jika ibu tidak mengetahui cara melakukan pengukuran suhu yang benar (salah dalam membaca hasil pengukuran dan salah menggunakan alat) sehingga akan menyebabkan tatalaksana yang tidak tepat seperti pemberian obat antipiretik yang tidak sesuai, lambat dalam membawa anak untuk diperiksa ke pelayanan kesehatan, dll yang dikhawatirkan dapat membahayakan kondisi anak (Chiappini, Bortone, Galli, \& de Martino, 2017; Korkut, Y, 2018)

Berdasarkan data diatas, maka tim dari Universitas Sari Mulia Banjarmasin tergerak untuk melakukan peninjauan masalah di lapangan dan pengabdian kepada masyarakat. Harapannya kegiatan ini dapat meningkatkan pengetahuan orangtua dalam memahami konsep demam dan tatalaksananya pada anak terutama di Kelurahan Manarap Lama sehingga orangtua menjadi percaya diri dalam menangani 
demam yang dialami anak. Setelah

dilakukan pengkajian dan wawancara singkat bersama, maka masalah konkret yang muncul pada mitra antara lain:

1. Ibu/orang tua belum terlalu memahami tentang pengetahuan demam: kurang mengetahui tentang cara pengukuran suhu tubuh, batas ambang suhu normal, dan kapan dibawa kepelayanan kesehatan.

2. Ibu/orangtua kurang paham tentang terapi non farmakologi: masih ada yang mengompres dengan air dingin dan menggunakan pakaian tebal saat anak demam.

3. Ibu/orangtua kurang paham tentang terapi farmakologi: tidak tahu dosis pemberian obat untuk anak demam dan efek samping dari pemberian obat parasetamol.

\section{B. METODE}

Adapun metode pelaksanaan kegiatan dibagi menjadi empat tahap, yaitu persiapan, observasi dan wawancara implementasi, serta evaluasi. Tahapan persiapan meliputi membuat surat tugas untuk pelaksanaan kegiatan PKM ke
LPPM Universitas Sari Mulia, meminta perijinan terkait rencana pelaksanaan kegiatan PKM kepada Lurah Manarap Lama dan pendekatan kepada tokoh masyarakat. Selain itu, mempersiapkan pembuatan standing banner oleh mahasiswa untuk nanti bisa diberikan kepada Bapak Lurah sebagai media informasi agar bisa dipasang dikantor Kelurahan dan dapat dibaca oleh warga saat berkunjung, membeli alat thermometer yang nanti akan diberikan dan diajarkan kepada warga yang mengikuti kegiatan PKM.

Tahap berikutnya yaitu tahap observasi dan wawancara untuk menggali lebih dalam terkait permasalahan yang terjadi dilapangan. Adapun kegiatan dibantu pelaksanaannya oleh mahasiswa dan proses dilakukan selama kurang lebih 3 hari (tanggal 19 - 21 Juni 2021). Mahasiswa melakukan kunjungan dan wawancara dengan orangtua yang memiliki anak untuk mengetahui terkait tatalaksana demam untuk anak. Sebelumnya dibuat kerangka acuan untuk wawancara agar semua 
pertanyaan yang ditanyakan kepada partisipan (orangtua) sama dan lebih terarah. Adapun jumlah pertanyaan terdiri 3 poin utama yaitu pengetahuan tentang konsep demam terdiri atas 8 pertanyaan, pengetahuan tentang terapi non farmakologi terdiri atas 5 pertanyaan dan pengetahuan tentang terapi farmakologis terdiri atas 5 pertanyaan. Total semua pertanyaan adalah 18 soal. Semua hasilnya nanti akan ditelaah ulang, dinarasikan dan disimpulkan bersama tim sehingga terumuskan masalah yang terjadi.

Tahap pelaksanaan meliputi kegiatan Edukasi dan Pelatihan Tatalaksana Demam pada Anak kepada orangtua. Kegiatan dilaksanakan pada tanggal 09 Juli 2021. Ada 3 topik yang disampaikan dalam kegiatan tersebut yaitu tentang konsep demam dan bahayanya, perawatan demam pada anak di rumah, dan penggunaan obat paracetamol pada anak serta ditambah adanya praktik terkait pengukuran suhu tubuh dengan menggunakan thermometer aksila, cara melakukan kompres dan seka pada bayi yang mengalami demam serta melakukan perhitungan dosis obat parasetamol untuk menurunkan demam. Sebelum dan setelah dilaksanakan kegiatan pemberian edukasi dan pelatihan ini, dilakukan pengukuran pengetahuan orangtua dengan memberikan kuesioner berjumlah 12 soal. Kendala yang dihadapi saat kegiatan adalah sulitnya mengumpulkan sasaran yang tepat waktu dan tidak semua undangan berhadir.

Tahap berikutnya adalah kegiatan evaluasi atas program yang telah dilaksanakan. Evaluasi dilakukan melalui observasi dan wawancara kembali kepada beberapa orangtua yang telah berhadir dalam kegiatan PKM untuk meninjau keberhasilan dan keberlanjutan program yang dilaksanakan. Tahap evaluasi dilakukan seminggu setelah kegiatan PKM dilakukan.

\section{HASIL DAN PEMBAHASAN}

Hasil kegiatan dari PKM yang berjudul "Edukasi dan Pelatihan Tatalaksana Demam pada Anak di Kelurahan Manarap Lama dapat diuraikan pada tabel 1.1 


\section{Tabel 1.1 Hasil Proses Kegiatan PKM}

\begin{tabular}{|c|c|c|c|}
\hline No & Waktu & Kegiatan & Hasil \\
\hline 1 & $\begin{array}{l}19-21 \text { Juni } \\
2021\end{array}$ & $\begin{array}{l}\text { Observasi dan wawancara kepada } \\
\text { orangtua terkait pengetahuan } \\
\text { tentang tatalaksana demam pada } \\
\text { anak }\end{array}$ & $\begin{array}{l}\text { Didapatkan hasil bahwa ada } \\
\text { beberapa orangtua ada yang } \\
\text { tidak memahami terkait } \\
\text { konsep demam dan tatalaksana } \\
\text { demam pada anak }\end{array}$ \\
\hline 2 & 09 Juli 2021 & $\begin{array}{l}\text { Edukasi dan pelatihan tatalaksana } \\
\text { demam pada anak }\end{array}$ & $\begin{array}{c}\text { Terdapat perbedaan } \\
\text { pengetahuan orangtua sebelum } \\
\text { dan sesudah diberikan edukasi } \\
\text { dan pelatihan tatalaksana } \\
\text { demam pada anak }\end{array}$ \\
\hline 3 & 19 Juli 2021 & 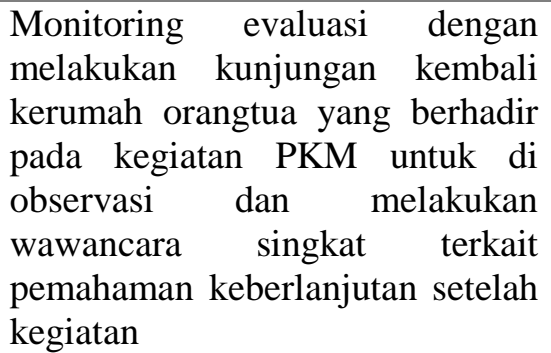 & $\begin{array}{l}\text { Orangtua masih mengingat } \\
\text { terkait hal-hal yang } \\
\text { disampaikan saat kegiatan } \\
\text { edukasi dan pelatihan. Dan } \\
\text { berupaya melakukan terus } \\
\text { menerus apa yang sudah } \\
\text { diinformasikan }\end{array}$ \\
\hline
\end{tabular}

Gambar 1. Kegiatan observasi dan wawancara pada orangtua

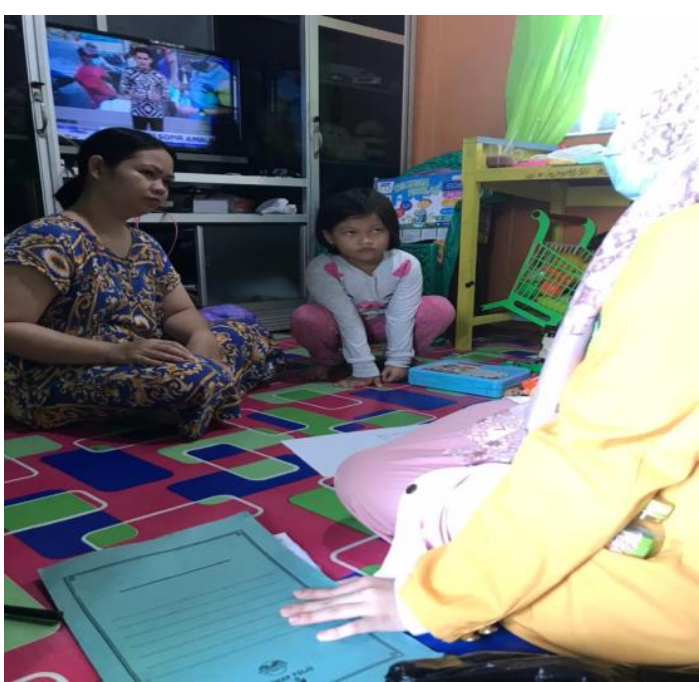

Saat kegiatan observasi dan wawancara kepada para orangtua yang memiliki anak tampak kooperatif menjelaskan terkait halhal yang ditanyakan. Didapatkan hasil bahwa ada beberapa keluarga yang tidak mengetahui tentang

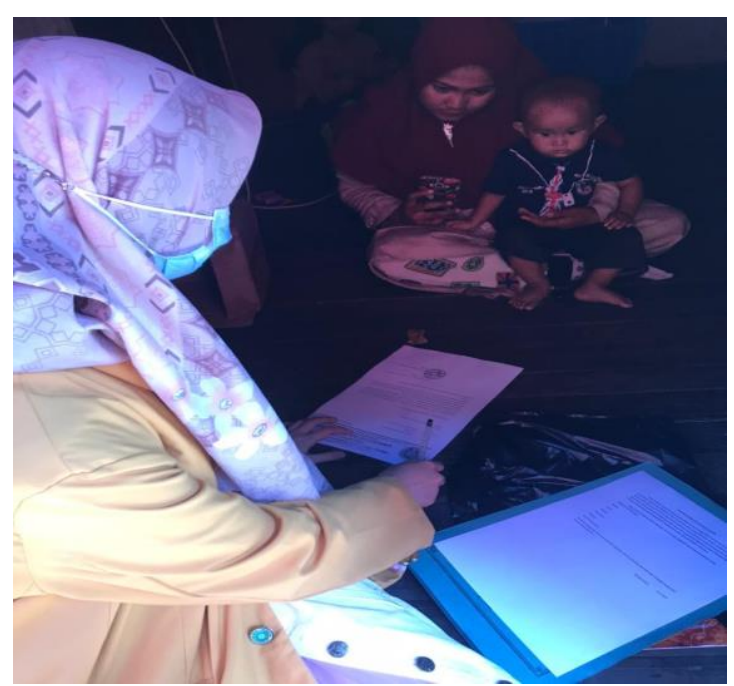

konsep demam dan tatalaksana demam pada anak. Kebanyakan orangtua hanya melakukan pengukuran suhu tubuh menggunakan telapak tangan dan biasanya menggunakan kompres es/ dingin saat anak demam, memakai 
pakaian tebal agar anak tidak

kedinginan serta bingung dalam menghitung dosis obat paracetamol

(paling hanya lihat dikemasan saja).

Gambar 2. Kegiatan edukasi dan pelatihan tatalaksana demam pada anak

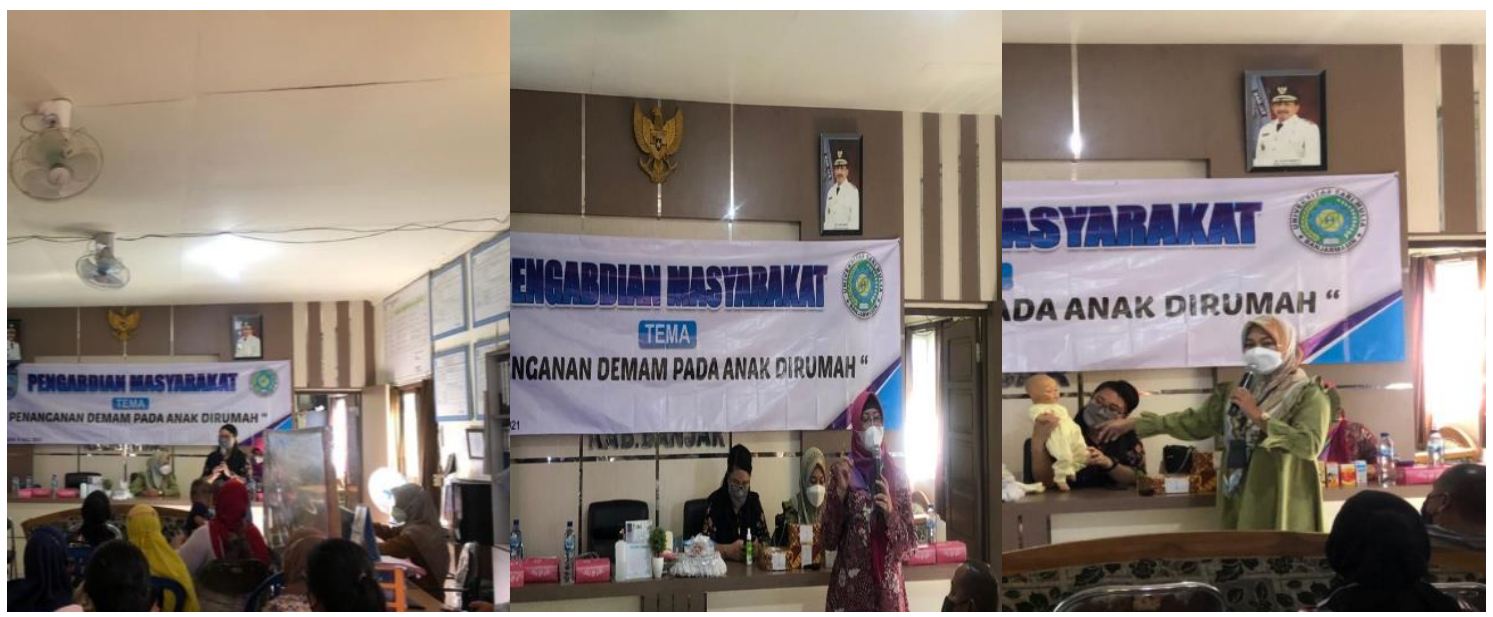

Gambar 3. Praktik Terkait Cara Tatalaksana Demam
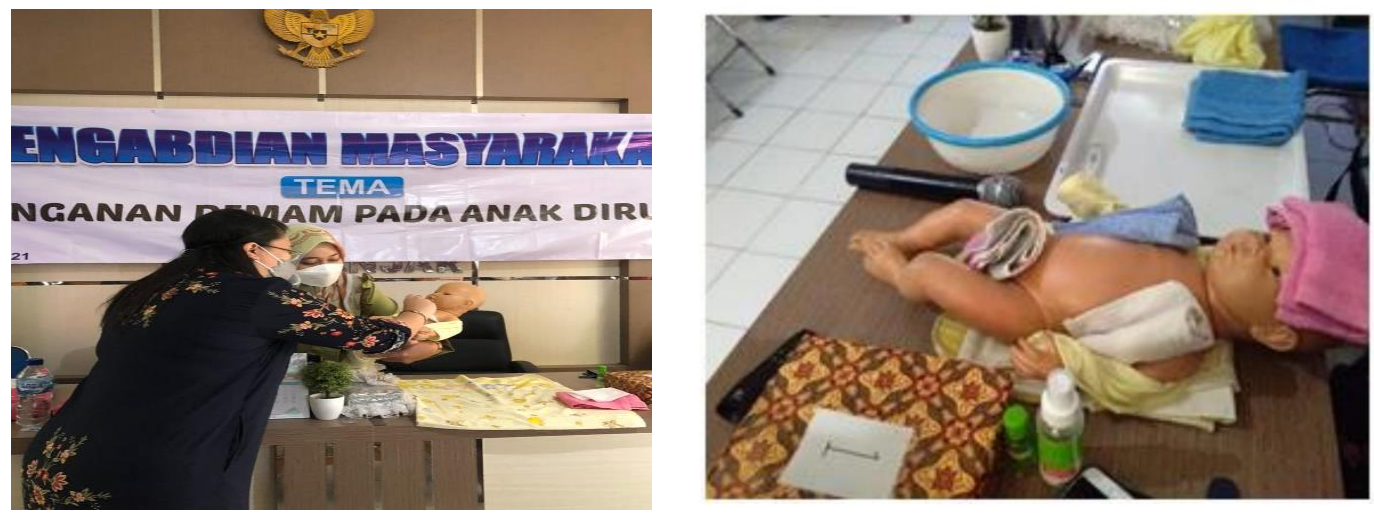

Gambar 4. Evaluasi Kegiatan :Pengisian kuesioner pre test dan post test
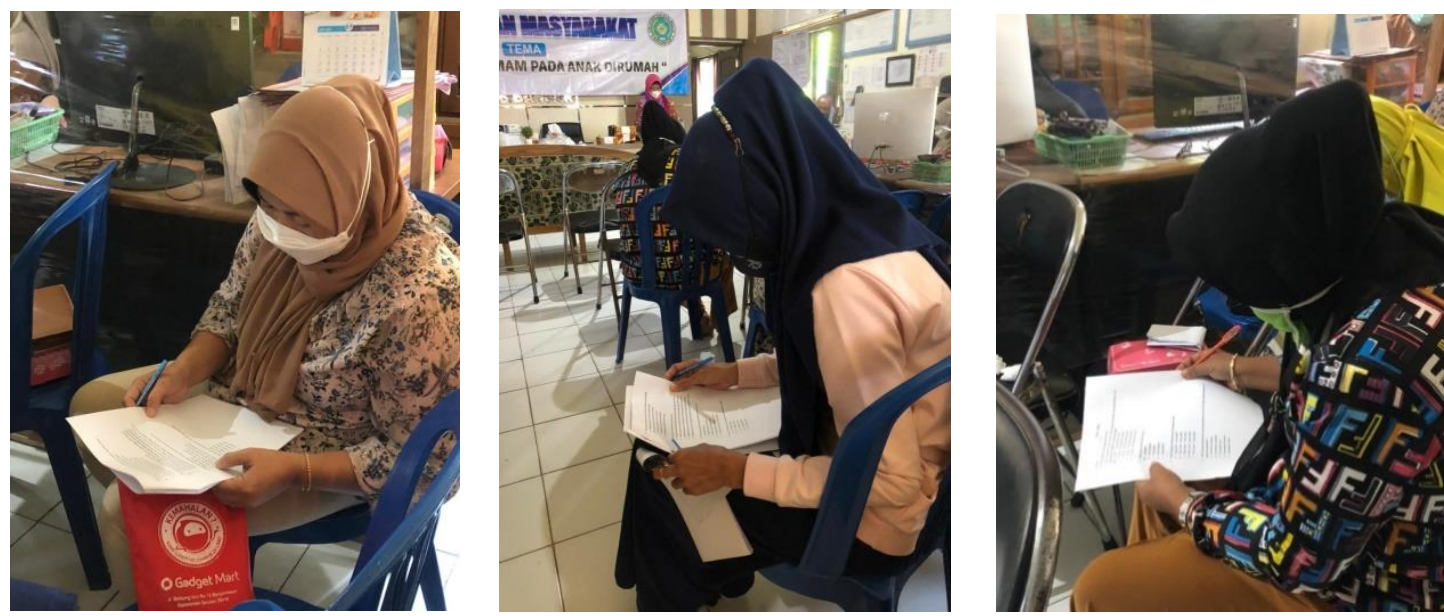

Page $92 \mid 96$ 


\section{Gambar 5. Kegiatan Evaluasi Pasca Kegiatan Pengabdian Masyarakat}

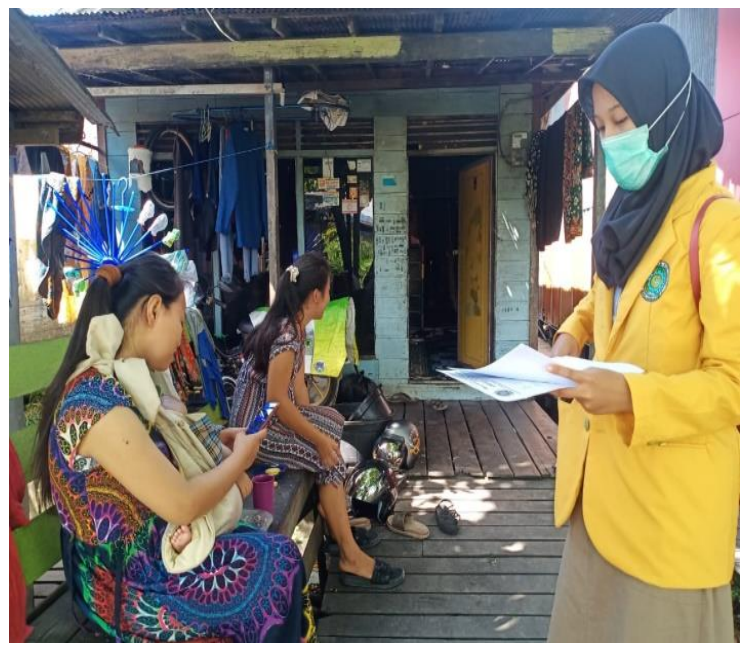

Berikut hasil pre test dan post test dalam menjawab kuesioner pada kegiatan edukasi dan pelatihan yang dilaksanakan dijabarkan pada tabel 1.2 dibawah ini:

\begin{tabular}{|c|l|c|c|}
\hline No. & \multicolumn{1}{|c|}{ Nama } & $\begin{array}{c}\text { Nilai } \\
\text { Pre- } \\
\text { test }\end{array}$ & $\begin{array}{c}\text { Nilai } \\
\text { Post- } \\
\text { test }\end{array}$ \\
\hline 1. & Ny. NH & 36 & 74 \\
\hline 2. & Ny. R & 27 & 64 \\
\hline 3. & Ny. N & 36 & 68 \\
\hline 4. & Ny. F & 45 & 85 \\
\hline 5. & Ny. SA & 27 & 62 \\
\hline 6. & Ny. DK & 36 & 72 \\
\hline 7. & Ny. F & 27 & 62 \\
\hline 8. & Ny. M & 18 & 50 \\
\hline 9. & Ny. FZ & 18 & 51 \\
\hline 10. & Ny. Mr & 36 & 62 \\
\hline 11. & Ny. R & 18 & 52 \\
\hline 12. & Ny. Mi & 27 & 60 \\
\hline 13. & Ny. Ma & 27 & 62 \\
\hline 14. & My. A & 18 & 51 \\
\hline & Rata-rata & 28,3 & 62,5 \\
\hline
\end{tabular}

Hasil menunjukkan pada nilai pre test didapatkan rentang nilai antara $18-45$, sedangkan nilai post

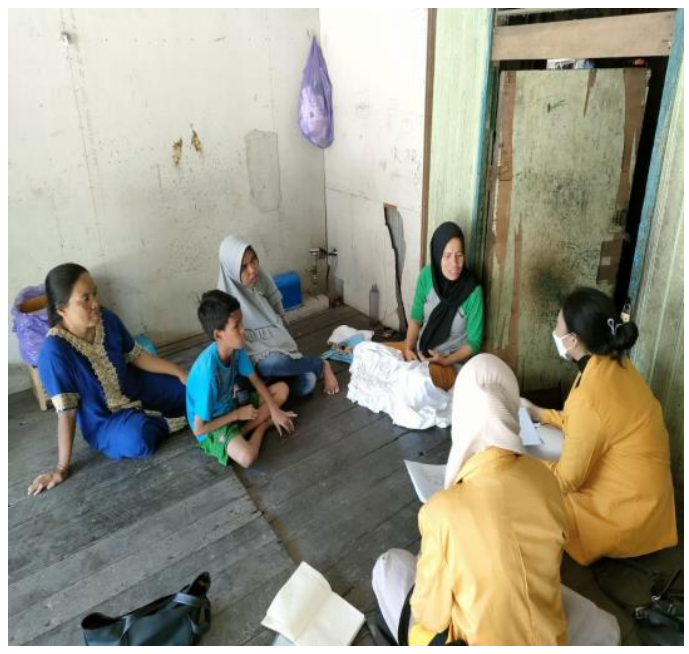

test didapatkan rentang nilai antara $50-85$. Terdapat perbedaan ratarata nilai pre test dan post test yaitu 28,3 dan 62,5 . Terdapat peningkatan pengetahuan orangtua setelah dilaksanakan edukasi dan pelatihan terkait tatalaksana demam pada anak. Saat kegiatan dilakukan, beberapa ibu antusias untuk bertanya.

Pentingnya seorang ibu meningkatkan pengetahuan dalam melakukan penangan demam pada anak. Jika pengetahuan ibu kurang terkait penangan demam maka dikhawatirkan akan memperlambat proses penyembuhan demam pada anak dan dikhawatirkan membahayakan kondisi anak. Pengetahuan dan pengalaman seorang ibu dalam menangani suatu 
masalah atau penyakit pada anak, salah satunya tentang demam sangat diperlukan. Ibu harus tau bagaimana menangani dan memberikan perawatan yang tepat agar mencegah komplikasi sehingga tidak menyebabkan gangguan tumbuh kembang pada anak dikemudian hari (Langingi, Akbar, \& Kaseger, 2020).

Pemberian edukasi kesehatan untuk orangtua dapat membantu mengurangi penggunaan antipiretik yang tidak tepat, mengurangi ketergantungan terhadap pelayanan Kesehatan dan meningkatkan pengetahuan tentang demam dan tatalaksananya. Meningkatkan pengetahuan orangtua tentang pencegahan terjadinya kejang demam pada anak dapat membantu mengurangi kecemasan dan kekhawatiran orangtua. Pemberian edukasi juga membantu meningkatkan kepercayaan diri orangtua dalam melakukan pencegahan kejang demam. Sebagai seorang perawat memiliki peranan penting dalam mendidik orangtua/ ibu tentang pengobatan berbagai penyakit pada anak khususnya terkait tatalaksana demam pada anak (Herman \& Nurshal, 2017).

\section{KESIMPULAN}

Kegiatan PKM yang dilakukan ini disambut hangat oleh pihak Kelurahan, Puskesmas setempat dan masyarakat terutama orangtua. Orangtua merasa bersyukur kegiatan ini dilaksanakan sehingga bisa meningkatkan pengetahuan terkait tatalaksana demam pada anak. Terdapat perbedaan pengetahuan sebelum dan setelah dilakukan edukasi dan pelatihan dibuktikan dengan hasil kuesioner dan wawancara sebelum kegiatan dilaksanakan. Kurangnya edukasi yang dilakukan sebelum adanya kegiatan ini membuat masyarakat kurang mengetahui bagaimana tata laksana penanganan demam pada anak di rumah sehingga banyak masyarakat yang keliru dengan cara penanganan demam pada anak dirumah. Harapannya setelah kegiatan ini orangtua lebih memahami tentang pengetahuan demam pada anak, seperti mengukur suhu menggunakan termometer, pencegahan gejala demam secara farmakologi dan nonfarmakologi. 
Selain itu juga bisa meningkatkan kepercayaan diri orangtua, mengurangi kecemasan dan

\section{DAFTAR PUSTAKA}

Barbi, E, Marzuillo, P, Neri, E, Naviglio, S, Krauss, BS. (2017). Fever in children: pearls and pitfalls', Children, 4(81), 1-19. https://doi.org/10.3390/children40 90081

Butarbutar, M. H., Sholikhah, S., \& Napitupulu, L. H. (2018). The Relationship of Knowledge and Attitude about Fever and its Treatment in Children at Shanty Clinic Medan. Preventif: Jurnal Kesehatan Masyarakat, 53-57. http://jurnal.untad.ac.id/jurnal/ind ex.php/Preventif

Chiappini, E., Bortone, B., Galli, L., \& de Martino, M. (2017). Guidelines for The Symptomatic Management of Fever in Children: Systematic Review of The Literature and Quality Appraisal with AGREE II. BMJ Open, 1 - 10. http://dx.doi.org/10.1136/bmjopen -2016-015404

Doloksaribu, T. M., \& Siburian, M. (2017). Pengetahuan Ibu dalam Penanganan Demam pada Anak Balita (1-5 tahun) di RSU Fajar Sari Rejo Medan Polonia Tahun 2016. Jurnal Ilmiah PANNMED, vol. 11, no. 3, 213-216. https://doi.org/10.36911/pannmed. v11i3.103

Herman, H., \& Nurshal, D. (2017). The Effect of Health Education to Parent's Behaviours on Managing ketakutan dalam melakukan tatalaksana demam pada anak terutama saat di rumah.

Fever in Children. International Journal of Research in Medical Sciences, 5(11), 4701 - 4707. http://dx.doi.org/10.18203/23206012.ijrms20174919

Kristianingsih, A., Sagita, Y, D., \& Suryaningsih, I. (2019). Hubungan Tingkat Pengetahuan Ibu Tentang Demam Dengan Penanganan Demam Pada Bayi 0-12 Bulan Di Desa Datarajan Wilayah Kerja Puskesmas Ngarip Kabupaten Tanggamus Tahun 2018. Midwifery Journal, 4(1), 26-31. https://doi.org/10.31764/mj.v4i1.5 $\underline{10}$

Korkut, Y. (2018). Mothers' Knowledge and Management of Fever in Febrile Children. Family Practice and Palliative Care, 3(3), 113 116.

https://doi.org/10.22391/fppc.370 $\underline{931}$

Langingi, A. R. C., Akbar, H., \& Kaseger, H. (2020). Pengaruh Penyuluhan Kesehatan terhadap Tingkat Pengetahuan Ibu dalam Menangani Demam pada Anak di Desa Moyag Todulan, Graha Medika Nursing Journal, 3(1), 1 9

https://journal.iktgm.ac.id/index.p hp/nursing/article/view/81

Rifaldi, I., \& Wulandari, D. K. (2020). Efektifitas Pemberian Kompres Tepid Water Sponge dan Pemberian Kompres Bawang Merah terhadap Penurunan Suhu 
Tubuh Anak Demam di Banjarmasin, Kalimantan Selatan. Jurnal Keperawatan Suaka Insan (JKSI), vol. 5, no. 2, 175 - 181.

https://doi.org/10.51143/jksi.v5i2. $\underline{247}$
Surya, M. A. N. I, \& Artini, I. G. A. (2018). Pola penggunaan parasetamol atau ibuprofen sebagai obat antipiretik single therapy pada pasien anak. E-Jurnal Medika Udayana, 7(9), 1 - 13. https://ojs.unud.ac.id/index.php/eu $\underline{\mathrm{m} / \text { article/view/42565 }}$ 